\title{
Foreign Capital and International Division Trap
}

\author{
Wenming Yuan ${ }^{1}$ \\ ${ }^{1}$ School of Economics, Qing Dao University, Qing Dao, China \\ Correspondence: Wenming Yuan, PhD, School of Economics, Qing Dao University, Qing Dao, China.
}

Received: March 5, 2018

doi:10.5430/ijfr.v9n2p227

Accepted: April 2, 2018

Online Published: April 19, 2018

URL: https://doi.org/10.5430/ijfr.v9n2p227

\begin{abstract}
The paper used the panel data from 2000 to 2014 of 9 developing economies to research the effect of FDI on GVC-participation of host countries and International Division of Labor Trap from the two dimensions of theory and demonstration. And further researches are carried on, which shows that FDI is beneficial of deepening GVC-participation of developing host countries. Furthermore, FDI has solidified the international division of labor by driving the developing host countries participate into the international production system leading to be fallen into the trap of international division of labor. FDI has solidified the level of international division of labor in developing host countries through the pre embedded "GVC", and the backward embedding of GVC is good for the separate developing host countries from the bottom Division. Among the three mechanisms, Scale effect and cluster effect could not be beneficial for developing host countries to separate from the bottom of Division. The learning by doing effect and path locking effect in Inherent division of labor further lead to be fallen in the international division of labor trap.
\end{abstract}

Keywords: FDI, GVC participation, international division of labor

\section{Introduction}

With refinement of international division, the international production system has deeply developed, and FDI has already been an important tool. And throughout the development process of economic globalization, both FDI and the integration of world economy promote each other, which drive worldwide economy to be an indivisible whole. The development speed of FDI has further speed up especially when the International production enters into intra product trade stage, which lets economies deeply embedded in the global value chain division of labor. According to the 2016 world investment report issued by the UN World Trade Center Development Commission, the global FDI quickly grows up in 2015, which is a 38\% increase of the year before, and the total amounted to 1 trillion and 760 billion U.S. dollars. East Asian and Southeast Asian countries show better performance among them. The presence of FDI has not only deepened the participation of the "GVC" in the Middle East but also plays an important role in exports structure and international division of labor of host countries.

Traditionally, FDI makes up for the gap between the host country's capital and technology. And meanwhile, it positively affects employment and upgrading of industrial structure. The academy has also launched a study for half a century of FDI and influence the economic growth of the host country (Borensztein et al. Aitken et, 1998; al., 1999; Shen Kunrong, Geng, 2001). With the mature of researches of global value chain, the international division status is very important for value chain, and hence the importance of international division status of a country's economy is growing up. But there is little research focused on the effect of FDI on the changes of the host pattern of international division of labor. Most of the developing countries are still at the bottom of the international division of labor, except for the upgrading status of "four small economies" in East Asia, which is difficult to go to the high-end of the global value chain and become trapped in the international division of labor trap.

According to the analysis above, the paper focuses on that host countries are embedded into GVC by FDI and the role of FDI playing in the promotion of the international division of labor in developing host countries. Considering that the fact of developing countries has fallen into the trap of international division of labor for a long time, whether FDI has played a role or not could be a question. The paper used panel data from 2000 to 2014 of 9 developing countries to firstly analyze the influence of FDI on participation of host countries in GVC. Further, the paper studies the relationship between FDI and the developing host countries fallen into the trap of international division of labor 


\section{Analysis of Influence Mechanism}

The influence of FDI on international division of labor is firstly based on the fact that FDI could embed host countries into international division of labor to a large extent, leading host countries to deeply embed into GVC and form a pattern of international division of labor. And hence the influence mechanism of FDI on the global value chain of the host country is listed before the analysis concerning the influence of FDI on international division trap.

\subsection{The Influence Mechanism of FDI on the Impaction of the Global Value Chain of the Host Country}

In the past, FDI focused on producing specific goods, mainly aimed at taking advantage of the low production elements of the host country, or even avoided high tariffs and trade barriers. Now FDI is more inclined to product specific production stage, and has become the main way for multinational companies to allocate production globally and minimize costs. However, this process will gradually embed the host country into the division of global value chain.

Economies embedded in global value chain are divided into forward embedding and backward embedding. Forward embedding means to import foreign intermediate goods for export, which generally is showed by foreign added value share of export goods (Upward et al., 2013; Lv 2015), namely the degree of use of foreign intermediate goods are used to export. Backward embedding refers to the extent of use of domestic intermediate goods created export value added by other economies. It is also one of the embodiments of a country's embedding in the global value chain. The vertical production network of multinational companies is mainly supplied by the intermediate flow (Hanson et al., 2005), and the subsidiary or branch form the FDI upstream of the foreign parent company's demand and downstream intermediate goods intermediate goods supply and improve the developing countries into the extent of the GVC. Li and Liu (2016) measured the impact of FDI on intermediate imports by using China's panel data. The results show that $1 \%$ of FDI will drive $0.345 \%$ of intermediate imports. Furthermore, the FDI of low cost seeking type is used as an example and is mainly based on the global optimal production location, and the developing countries is the optimal location of assembly process, assembly process of intermediate goods exports will deepen ties with the international market of host country. In addition to the direct effect of forward and backward embedding, after FDI entry, the vertical and horizontal production link is generally established based on local market and domestic enterprises. And local market and domestic enterprises to establish a vertical type and horizontal type production based on the cultivation of the competitiveness of local enterprises will overflow and diffusion technology (Blomstrom \& Sjoholm, 1999), local enterprises to expand the market demand will lead to local enterprises export of intermediate goods, indirectly prompting the host embedded in GVC.

\subsection{Influence Mechanism of FDI on International Division Trap}

FDI could embed developing host countries into international labor system, which solidified international division of labor. But it is hard to go to the high end, and to fall into the international division of labor trap. The detail influence mechanism includes the dry learning effect of the inherent division of labor; the scale effect of the specific division of labor and the cluster effect; the path locking effect

\subsubsection{The Effect of "Learning by Doing" in the Position of Inherent Division of Labor}

The entry of FDI further refines the market division of labor in the developing host countries and the FDI host countries will focus more on the value chain production links with comparative advantages in the global value chain. Production factors and focus on the low-end of the value chain will achieve higher productivity in the "dry" under the effect of comparative advantage in the low-end division to further highlight the developing countries will be further consolidated in the division phase inherent (Balasubramanian \& Lieberman, 2011). Sun Churen et al. (2008) using the panel data of China show that the development of China's processing trade is obviously driven by FDI, and the improvement of processing trade productivity has further attracted more FDI.

\subsubsection{The Scale Effect of Specific Division of Labor and Cluster Effect}

The downstream links of the GVC division of labor are concentrated in labor-intensive industries. The advantages of the international division of labor in developing countries are mainly concentrated. The presence of FDI promotes the marginal output of the factors of production in this link, thus increasing the price of production factors. The price of production factors to improve production factors to further stimulate the convergence point of assembly process, and will attract other production elements into the link, the formation of scale and the cluster effect of the strong link, the international division of labor status has been further consolidated. Feenstraa \& Hansonb (1997) found that the use of 1975-1988 in Mexico border processing industry data, FDI led to the production and assembly of industrial workers wages, the labor force to further attract non border areas into the region, strengthen the region's assembly position. 


\subsubsection{Path Locking Effect}

first of all, the main way of promotion of international division ranking is to rely on their technology progress (Grossman \& Helpman, 2005), FDI inflows to developing countries engaged in a higher proportion of processing trade, and Lv Yue (2017) found through processing trade embedded in "GVC", is not conducive to their technology progress, so FDI brings high proportion of processing trade lag the promotion of the "GVC" position of the division of labor. In the dynamic sense, processing trade makes developing countries far away from "GVC" high-end links, and the gap with the high-end status of developed countries is far away, further produce the path dependence and low-end division of labor locked pattern (Wang Lan, Li Hongyan, 2015). Secondly, the development of the early development of the host country to the infant industry and developed economies to compete, while FDI is in more damage to the original path of development of infant industries, blocked can drive the developing countries to achieve the status of "GVC" promotion division of leading industry, further path of international division of labor status of the lock. Finally, provides more cheap imports of intermediate goods GVC embedding process for FDI host (Kelly, 2004), intermediate goods are produced in the country of import substitution, while the cost of the entire value chain is reduced, the country without production comparative advantage is difficult to grow, and was again blocked in original comparative advantage.

\section{Model and Data}

\subsection{Model}

Firstly, the model expresses the influence of FDI on GVC participation of host countries is below

$$
F V A R_{i t}=c+\alpha F D I_{i t}+\sum_{j=1}^{n} \beta_{j} \text { Contral }_{i t}+u_{i}+u_{t}+\varepsilon_{i t}
$$

Among them, FVAR ${ }_{i t}$ expresses the participation degree of GVC, $F D I_{i t}$ shows foreign direct investment capital, Contral $_{i t}$ refers to control variables.

Secondly, the model of the inflence of FDI on international division trap is established as below

$$
\begin{aligned}
& \operatorname{Trap}_{i t}=c+\alpha_{1} F D I_{i t}+\alpha_{2} F D I_{i t} * F_{V A R}{ }_{F-i t}+\alpha_{3} F D I_{i t} * F V A R_{B-i t}+\alpha_{4} F D I_{i t} * \text { Process }_{i t} \\
& +\alpha_{5} F D I_{i t} * G V C_{i t}^{\text {pisition }}+\alpha_{6} F D I * \text { Wage }_{i t}+\sum_{j=1}^{n} \beta_{j} \text { Contral }_{i t}+\mu_{i}+\mu_{t}+\varepsilon_{i t}
\end{aligned}
$$

Among them, Trap ${ }_{i t}$ represents the degree of host countries falls in the trap, FVAR ${ }_{F-i t}$ refers to the forward embedding degree of GVC, while FVAR ${ }_{\text {B-it }}$ shows the backward embedding degreee of GVC. Process $i$, Wage $_{i t}$ GVC $_{i t}^{\text {position }}$ shows Proportion of processing trade, average wage of manufactury and global value chain respestively, and the interaction term is applied to reflect the impact of three different paths. Total factor productivity level, Independent R \& D investment and factor endowment level

\subsection{Core Explained Variables and Control Variables}

\subsubsection{FDI Stock}

The inflow of FDI in the developing host countries has only the traffic data over the years, and perpetual inventory method is applied to make inventory of the traffic data.

\subsubsection{GVC Precedence}

According to the GVC status index constructed by Koopman et al. (2014)

\subsubsection{The Proportion of Processing Trade}

In the sample economies, only the Chinese customs database published the proportion of processing trade over the years, so it is necessary to calculate the proportion of processing trade in the rest of the sample countries. The processing trade mainly utilizes the cheap production elements in the processing and assembly links of the developing economies, and then exports the whole or part of the raw materials after processing. The core is that the import of intermediate commodities leads to the export of the final commodities, so the contribution of the intermediate commodity import to the export of the final commodities is the degree of the economic processing trade, and the original data is still based on the WIOD database (Note 1) 


\subsubsection{Based on WIOD Database Accounting Variable Index}

\subsection{Basic Accounting Framework}

Based on the WIOD database, the paper calculates the variable index, including the added value of foreign intermediate goods created in the export commodities, the added value of domestic intermediate commodities, the added value of the total export, and the added value of each industry export and its proportion. Referring to the method of Sterner (2012), the input output table is abstracted into the following form

Table 1. World non competitive input output table

\begin{tabular}{|c|c|c|c|c|c|c|c|c|c|c|}
\hline \multirow{2}{*}{$\begin{array}{l}\text { Output } \\
\text { Input }\end{array}$} & & \multicolumn{4}{|c|}{ Intermediate goods } & \multicolumn{4}{|c|}{ Final goods } & \multirow{2}{*}{$\begin{array}{l}\text { Gross } \\
\text { output }\end{array}$} \\
\hline & & Country 1 & Country 2 & ........ & Country $r$ & Country 1 & Country 2 & ....... & Country $r$ & \\
\hline \multirow{4}{*}{ 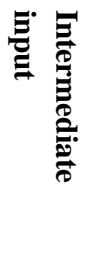 } & Country 1 & $X_{11}$ & $X_{12}$ & $\ldots \ldots$ & $X_{1 r}$ & $F_{11}$ & $F_{12}$ & $\ldots \ldots$ & $F_{l r}$ & $X_{I}$ \\
\hline & Country 2 & $X_{21}$ & $X_{22}$ & $\ldots \ldots$ & $X_{2 r}$ & $F_{21}$ & $F_{22}$ & $\ldots \ldots$ & $F_{2 r}$ & $X_{2}$ \\
\hline & $\ldots \ldots$ & $\ldots \ldots$ & $\ldots \ldots$ & $\ldots \ldots$ & $\ldots \ldots$ & $\ldots \ldots$ & $\ldots \ldots$ & $\ldots \ldots$ & $\ldots \ldots$ & $\ldots \ldots$ \\
\hline & Country $r$ & $X_{r l}$ & $X_{r 2}$ & $\ldots \ldots$ & $X_{r r}$ & $F_{r l}$ & $F_{r 2}$ & $\ldots \ldots$ & $F_{r r}$ & $X_{r}$ \\
\hline \multicolumn{2}{|c|}{ Added value } & $V_{l}$ & $V_{2}$ & $\ldots \ldots$ & $V_{r}$ & & & & & \\
\hline \multicolumn{2}{|c|}{ Gross input } & $X_{1}$ & $X_{2}$ & $\ldots \ldots$ & $X_{r}$ & & & & & \\
\hline
\end{tabular}

Note: This table shows the basic model of world non-competitive input output table, and simplifies the input and output module of the industry.Among them, $X_{\mathrm{ij}}$ shows Value of intermediate commodities of I country to J country.

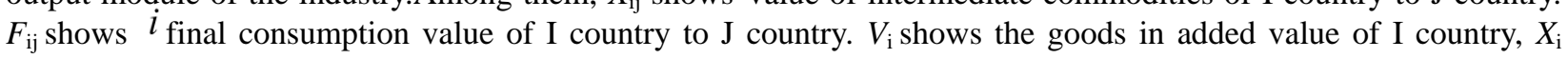
refers to the total output of I country

Based on the structure of the world non-competitive input output table, the following identities are obtained:

$$
X=A X+F=L F
$$

Among them, $\mathrm{X}$ is the total output vector of $\mathrm{CG}^{*} 1$. $\mathrm{C}$ presents the number of countries. G shows the number of industries. A is the input coefficient matrix of $\mathrm{CG}^{*} \mathrm{CG}$. $\mathrm{F}$ is the final consumption need vector of $\mathrm{CG} * 1 . \mathrm{L}=(\mathrm{I}-\mathrm{A})^{-1}$, $\mathrm{L}$ is namely the theory of international trade in the Leontief inverse matrix. To simplified analysis, the paper takes the model of the three countries as an example, and each country has only one industry. Supposed that the R, S, T country exist, and the identical equation is extended:

$$
\left[\begin{array}{l}
X_{r} \\
X_{s} \\
X_{t}
\end{array}\right]=\left[\begin{array}{ccc}
A_{r r} & A_{r s} & A_{r t} \\
A_{s r} & A_{s s} & A_{s t} \\
A_{t r} & A_{t s} & A_{t t}
\end{array}\right]\left[\begin{array}{l}
X_{r} \\
X_{s} \\
X_{t}
\end{array}\right]+\left[\begin{array}{l}
F_{r} \\
F_{s} \\
F_{t}
\end{array}\right]=\left[\begin{array}{lll}
L_{r r} & L_{r s} & L_{r t} \\
L_{s r} & L_{s s} & L_{s t} \\
L_{t r} & L_{t s} & L_{t t}
\end{array}\right]\left(\begin{array}{l}
F_{r r}+F_{r s}+F_{r t} \\
F_{s r}+F_{s s}+F_{s t} \\
F_{t r}+F_{t s}+F_{t t}
\end{array}\right)
$$

Among them, $X_{r}, X_{s}, X_{t}$ shows respectively the total output of the three countries. $F_{r}, F_{s}, F_{t}$ shows the final consumption of those countries, and the right side of equal sign represents the destination of the final consumer goods

3.2.3.1.2 The Added Value of Bilateral Export Trade (Including Total Value Added Value of Exports and Added Value of Intermediate Goods)

Based on the above model, the additional value of $\mathrm{R}$ country exporting to $\mathrm{s}$ country needs to calculate the added value of $\mathrm{R}$ country in the final consumption of s country. The added value of $\mathrm{R}$ in the final consumption in $\mathrm{s}$ contains mainly consists of three parts: first, including $s$ in the final consumer goods imported from China $\mathrm{r}$ in the country to create value; secondly, the creation of $\mathrm{R}$ in intermediate goods imports of final goods in country $\mathrm{s}$ in value; finally, finally consumer goods exported to $t \mathrm{~s}$ in the use of intermediate goods in the country of $\mathrm{R}$, created the middle part of the value of the goods. The equation is following.

$$
E x_{r s}=\left(v^{r}, 0,0\right)\left[\begin{array}{lll}
L_{r r} & L_{r s} & L_{r t} \\
L_{s r} & L_{s s} & L_{s t} \\
L_{t r} & L_{t s} & L_{t t}
\end{array}\right]\left(\begin{array}{l}
F_{r s} \\
F_{s s} \\
F_{t s}
\end{array}\right)
$$


$E x_{r s}=v^{r} L_{r r} F_{r s}+v^{r} L_{r s} F_{s s}+v^{r} L_{r s} F_{t s}$ could be obtained by extending the above formula. Among them, $v^{r}=V_{r} / X_{r}$ shows domestic value added rate in the process of R Country production. $v^{r} L_{r r} F_{r s}$ represents the additional value of the $\mathrm{R}$ country included in the final consumer goods of $\mathrm{R}$ country imported from $\mathrm{s}$ country. $v^{r} L_{r s} F_{s s}$ shows that the value created by $\mathrm{R}$ country' intermediate commodities used in the final commodities of $\mathrm{s}$ countries for the consumption of their own countries. $v^{r} L_{r s} F_{t s}$ shows that the value created by the intermediate goods imported from $\mathrm{R}$ country by $\mathrm{T}$ country in the final commodities of $\mathrm{s}$ country consuming $\mathrm{t}$ country. Transforming the Leontief inverse matrix, further accounting of $\mathrm{R}$ export added value to $\mathrm{s}$ in intermediate goods has created, is as follows

$$
E x_{I n-T i v a(r s)}=\left(v^{r}, 0,0\right)\left[\begin{array}{ccc}
0 & L_{r s} & L_{r t} \\
0 & L_{s s} & L_{s t} \\
0 & L_{t s} & L_{t t}
\end{array}\right]\left(\begin{array}{l}
F_{r s} \\
F_{s s} \\
F_{t s}
\end{array}\right)
$$

Thirdly, taking the export value added by R country to t country as an example, the calculation formula is as follows:

$$
E x_{r t}=\left(v^{r}, 0,0\right)\left[\begin{array}{lll}
L_{r r} & L_{r s} & L_{r t} \\
L_{s r} & L_{s s} & L_{s t} \\
L_{t r} & L_{t s} & L_{t t}
\end{array}\right]\left(\begin{array}{l}
F_{r t} \\
F_{s t} \\
F_{t t}
\end{array}\right)
$$

Furthermore, the added value created by the intermediate goods exported from R country to t country is expressed in the lower form:

$$
E x_{I n-T i v a(r t)}=\left(v^{r}, 0,0\right)\left[\begin{array}{lll}
0 & L_{r s} & L_{r t} \\
0 & L_{s s} & L_{s t} \\
0 & L_{t s} & L_{t t}
\end{array}\right]\left(\begin{array}{l}
F_{r t} \\
F_{s t} \\
F_{t t}
\end{array}\right)
$$

The Leontief inverse matrix does not change, the added value of country specific calculation, need to be adjusted to the ratio of value added to specific countries, and placed into the corresponding position, and the final consumer need the third part of the vector of final consumer goods export destination countries based on vector expansion can be obtained, the three part of the contents of the corresponding. A country's Accounting Intermediate goods exports to create value added value on the basis of the total exports, the first column of the Leontief inverse matrix is set to zero

\subsection{Total Export Trade Value Added Accounting}

Base on the model above, Calculation of trade value added by $\mathrm{R}$ country to s country and $\mathrm{t}$ country could be done. According to merging calculation of matrices, the following formula could be obtained by merging the trade added value of R country to s country and S country to R country.

$$
E x_{r}=\left(v^{r}, 0,0\right)\left[\begin{array}{lll}
L_{r r} & L_{r s} & L_{r t} \\
L_{s r} & L_{s s} & L_{s t} \\
L_{t r} & L_{t s} & L_{t t}
\end{array}\right]\left(\begin{array}{l}
F_{r s}+F_{r t} \\
F_{s s}+F_{s t} \\
F_{t s}+F_{t t}
\end{array}\right)
$$

The formula could be extended to the calculation of the value added by one country to the multinational trade. In the final vector of consumer goods, the total consumption vector of export destination country is added to the original basis, and then the accounting result of the export value of a country's multinational trade can be obtained. The industrial level is further refined on the basis of the total level accounting, and no more details

\subsection{Data Source and Samples Explanation}

Table 2. Data source is following

\begin{tabular}{lll}
\hline Variables & Name & Source \\
FVAR & The degree of GVC participation & WIOD database \\
FVARF & Forward embedding degree of GVC & WIOD database \\
FVARB & Backward embedding degree of GVC & WIOD database \\
FDI & Foreign direct investment stock & UNCTAD Database \\
Infras & Infrastructure (the length of railway line and the & World Bank Database \\
\hline
\end{tabular}




\begin{tabular}{lll}
\hline \multirow{2}{*}{ Market } & proportion of land area) & \\
& Marketization degree & World Bank Database \\
Endow & Factor endowment (proportion of industrial labor) & Memtech database \\
Trans & Ocean shipping cost & BAIDU MAP \\
Trap & The extent of international division of labor trap & WIOD database \\
Process & Proportion of processing trade & WIOD database \\
GVCposition & The value chain & WIOD database \\
Wage & Average wage of manufacturing workers & Memtech database \\
TFP & Total factor productivity level & Penn World Table (PWT 9) \\
R\&D & R \& D expenditure as a share of GDP & World Bank Database \\
\hline
\end{tabular}

Based on the data above, the paper chose panel data from 2000 to 2014 of 9 developing countries as a research sample. The lack is found from Memtech database, EU database and OECD database. WIOD database provided accounting over the years GVC status, degree of participation in GVC, the degree of forward and backward embedding, and export processing trade accounting basic data. Python language programming is applied for large matrix operation.

\section{Empirical Analysis}

The empirical analysis firstly aims to the link between FDI and GVC participation, and further research will be carried on to analyze the effect of FDI on International division trap.

\subsection{The Influence of FDI on GVC Participation}

Based on the model established above, the OLS regression, random effect of panel data and fixed effect regression, instrumental variable regression avoiding endogeny, Systematic GMM regression avoiding GVC participation inertia and the lag period of the explanatory variable are done respectively. The results are following.

Table 3

\begin{tabular}{llllll}
\hline & OLS & FE & RE & 2SLS & GMM \\
LnFDI & $0.158^{* * *}$ & $0.224 * * *$ & $0.382 * * *$ & $0.572 * * *$ & $0.540 * * *$ \\
& $(3.19)$ & $(5.37)$ & $(4.82)$ & $(6.67)$ & $(7.18)$ \\
L.FVAR & & & & & 0.332 \\
& & & & & $(1.32)$ \\
Fixed Individual & YES & YES & YES & YES & YES \\
Fixed year & YES & YES & YES & YES & YES \\
S arg an & & & & 0.223 & 0.563 \\
Ar(1) & & & & & 0.001 \\
Ar(2) & & & & & 0.475 \\
Wald & & & & & 960.32
\end{tabular}

$*, * *, * * *$ respectively expresses that the significant levels of $10 \%, 5 \%$ and $1 \%$, and the number in parentheses is the $\mathrm{t}$ statistic of coefficients, and the measuring software is Stata 12, which is still used in the subsequent measurement results and is no longer repeated

According to the above table, the coefficient of FDI is positively significant, which shows FDI enhances the GVC participation of developing host countries. The results of 2SLS regression using FDI's lag one as instrumental variables support this conclusion as well. While the dynamic panel GMM regression coefficient also did not change 
significantly. The entry of FDI increases imports and exports of developing host countries, and host countries further embedded into international production system. Among all the control variables, the coefficient of infrastructure is positive but not significant. And developing countries occupying the comparative advantage of processing trade need perfect logistics system to realize the smooth circulation of intermediate commodities. So the improvement of the transportation infrastructure represented by the railway line length is beneficial to the development of GVC participation in host countries. The market index coefficient is significantly positive, and the operation of international production system more perfect market mechanism based on the market, developing countries will further enhance the degree of convergence to the factors of production and the international market, relax domestic factors of production into the international market entry threshold. With the industrial sector accounted for labor factor endowment measure to promote the development of the host country into GVC depth of processing trade, as the comparative advantage of developing countries need a lot of industry, abundant labor industrial sector will be conducive to micro enterprises to undertake overseas orders. The increase in transportation costs is not conducive to developing countries embedded in the GVC depth, in line with expectations.

\subsection{The Influence of FDI on International Division Trap}

Further quantitative analysis has been done to research the influence of FDI on interational division trap. The results shows below

Table 4

\begin{tabular}{llllll}
\hline & OLS & FE & RE & 2SLS & GMM \\
LnFDI & $-0.323^{*}$ & $-0.153^{* *}$ & $-0.241^{* *}$ & $-0.541^{* * *}$ & $-0.599 * * *$ \\
& $(-1.67)$ & $(-2.46)$ & $(-2.33)$ & $(-2.89)$ & $(-3.11)$ \\
S arg an & & & & 0.152 & 0.490 \\
Ar(1) & & & & & 0.005 \\
Ar(2) & & & & & 0.241 \\
Wald & & & & & 1321.59 \\
\hline
\end{tabular}

On the whole, FDI is not conducive to the promotion of international division of labor score, FDI stationed dragged the host country to the promotion of the value chain. In the specific impact path, FDI mainly hindered the development of the international division of labor in the host countries through the GVC forward embedding. Forward embedding embodied imports of foreign intermediate goods and exports. The possible explanation is that the foreign intermediate goods imported by FDI are concentrated in the vertical division of labor within multinational corporations, which aims to make use of lower Production assembly cost of developing countries reflecting the expansion of the scale of processing trade, and hence it is not good for international division status promotion. On the other hand, backward embedding positively affect international division in host countries and separate from international division trap, which shows that FDI will produce vertical and horizontal production linkages with domestic manufacturers when supplying Intermediate goods oversea. And the spillover and diffusion of technology will lead the local enterprises in the host country to participate in the development of the whole industry chain, thereby enhancing the international division of labor. Among the three paths to affect international division trap, FDI hinders the development of the international division of labor in developing countries through scale effect and cluster effect and The dry learning effect and the path locking effect of the inherent division of labor further stifle the opportunities and momentum for developing countries to go to the high end of the value chain by comparing the coefficients of interaction terms. Among other control variables, the advance of TFP is good for sample economies to get rid of the trap of international division of labor. But the influence coefficient of independent $\mathrm{R} \& \mathrm{D}$ investment is smaller. The possible explanation is that the contribution of independent innovation investment to developing countries is far less than that of imitation innovation because of the distance from the innovation frontier. The factor endowment, which is measured by the proportion of the industrial labor force, is not conducive to the separation from the international division of labor trap, and the further policy tendency requires the developing countries to cultivate the high-end labor force needed in the upper level of GVC

\section{Conclusion}

While developing countries attract a large amount of FDI, the degree of GVC embedded is also driven. But the entry 
of FDI is not conducive to the development of the host country to the high-end of GVC and will lead to the development countries trapped in the international division of labor trap. Using the panel data of 9 developing economies for 2000-2014 years, this paper studies the influence of FDI on the GVC participation of the host country. The results showed that FDI deepened the GVC participation of developing countries, but the process solidified the pattern of international division of labor, resulting in the developing countries in the international division of labor trap. And effect is that forward embedding is not conducive to enhance the status of the international division of labor, while the backward embedding is conducive to the development of the promotion of the host country of international division of labor class. The dry learning effect, scale effect, cluster effect and path lock effect of the inherent division of labor further lead to the trap of the international division of labor in the developing host countries. On the whole, FDI restricts the driving force and opportunities of host countries to the high-end of GVC.

With the further refinement of the GVC division of labor and the need for global allocation of production factors, the proportion of foreign elements in each economy will become higher and higher in the total national economy. FDI accelerated the scale and speed of backward economies embedded in the global value chain, and provided a platform for their participation in international production. Based on the above conclusions, this paper further raises policy implications: the negative impact of FDI on developing countries in international division of labor class promotion needs appropriate caution in the process of introducing foreign capital. And more attention could be paid to the quality of foreign capital to accelerate the establishment of evaluation mechanism. And then the supervision of foreign administrative quality is established to avoid distortion of factor prices and general introduction of foreign investment behavior, regulate the local government investment behavior preventing the local government into the introduction of foreign capital malicious competition. The host country market oriented FDI is strictly distinguished from the host country factors of production oriented FDI .For the purpose of using the cheap production factors of the developing economies as the goal, the introduction of processing trade type FDI will be restricted under the premise of ensuring employment and local economic development At the same time, developing countries themselves should change the mode of introducing foreign capital, innovate the cooperation between foreign capital and domestic capital, and prevent the foreign capital from controlling the production factors of the industrial chain. Further could be done to cultivate domestic high-end production factors, protect the development of high-tech production links, exchange government policies for development space, and prepare for the promotion of GVC division of labor

\section{References}

Aitken, B. J., \& Harrison, A. E. (1999). Do Domestic Firms Benefit from Direct Foreign Investment? Evidence from Venezuela. American Economic Review, 89(3), 605-618. https://doi.org/10.1257/aer.89.3.605

Balasubramanian, N., \& Lieberman, M. (2011). Learning by Doing and Market Structure. The Journal of Industrial Economics, 59(2), 177-198. https://doi.org/10.1111/j.1467-6451.2011.00450.x

Blomstrom, M., \& Sjoholm, F. (1999). Technology Transfer and Spillovers: Does Local Participation with Multinationals Matter?. European Economic Review, 43(4), 915-923. https://doi.org/10.1016/S0014-2921(98)00104-4

Borensztein, E., Jose, D. G., \& Jong-Wha, L. (1998). How Does Foreign Direct Investment Affect Growth?. Journal of International Economics, 45(1), 115-135. https://doi.org/10.1016/S0022-1996(97)00033-0

Feenstraa, R. C., \& Hansonb, G. H. (1997). Foreign Direct Investment and Relative Wages: Evidence from Mexico's Maquiladoras. Journal of International Economics, 42(3), 371-393. https://doi.org/10.1016/S0022-1996(96)01475-4

Grossman, G. M., \& Helpman, E. (2005). Outsouring in a Global Economy. Review of Economic Studies, 72(1), 135-159. https://doi.org/10.1111/0034-6527.00327

Hanson, G. H., Matalon, R., \& Slaughter, M. J. (2005). Vertical Production Networks in Multinational Firms. Review of Economics and Statistics, 87, 664-678. https://doi.org/10.1162/003465305775098080

Kaplinsky, R., \& Morris, M. (2001). A Handbook for Value Chain Research. Prepared for the IDRC.

Kelly, W. (2004). International Technology Diffusion. Journal of Economic Literature, 43(1), 752-782.

Koopman, R., Wang, Z., \& Wei, S. J. (2014). Tracing Value-Added and Double Counting in Gross Exports. American Economic Review, 104(2), 459-494. https://doi.org/10.1257/aer.104.2.459

Li, H., \& Liu, K. (2016). Theoretical and empirical analysis of FDI's influence on trade mechanism of intermediate goods. Nankai Economics Research, 2, 116-128. 
Lv, Y., Huang, Y. X., \& Chen, Y. B. (2017). Productivity effect of global value chain Embeddedness: impact and mechanism analysis. World Economics, 7, 28-51.

Lv, Y., Luo, W., \& Liu, B. (2015). Heterogeneous firms and global value chain Embeddedness: from the perspective of efficiency and financing. World Economics, 8, 29-55.

Shen, K. R., \& Geng, Q. (2001). Foreign direct investment, technology spillover and endogenous economic growth. Chinese Social Sciences, 5, 82-93.

Stehrer, R. (2012). Trade in Value Added and the Value Added in Trade. WIOD Working Paper, 1-19.

Sun, C. R., Sheng, Y. L., \& Zhao, H. J. (2008). The relationship between FDI and processing trade: substitution, complementarity or other. Nankai Economics Research, 3, 84-103.

Upward, R., Wang, Z., \& Zheng, J. (2013). Weighing China's Export Basket: The Domestic Content and Technology Intensity of Chinese Exports. Journal of Comparative Economics, 41(2), 527-543. https://doi.org/10.1016/j.jce.2012.07.004

Wang, L., \& Li, H. Y. (2015). Research on the path of China's manufacturing industry integrating into global value chain -- from the perspective of embedded position and value-added capability. Chinese industrial economy, 2 , 76-88.

\section{Note}

Note 1. Using the industry panel data over the years, based on the OLS method to test the contribution of intermediate commodity imports to the final commodity export and to control the variables added to the TFP level and GDP growth rate over the years. 